\title{
How Can the Induction Programme be Influenced and Improved?
}

\author{
Linda A. Scheckle \\ Teaching and Learning Centre, Offices B17 University of Fort Hare \\ Private Bag X 9083, East London 5200 \\ Ischeckle@ufh.ac.za
}

\section{Doi:10.5901/mjss.2014.v5n11p77}

\begin{abstract}
The nature and worth of the Induction programme at an institution of higher education merited further investigation. Action research followed to establish continuation and the nature thereof. Methodology involved the gathering of qualitative and quantitative data. Four lenses provided an evaluation tool. The sample comprised of 67 inductees from various cycles, a peer, a consultant from a sister institution and seven voluntary presenters. Data collection tools consisted of a survey to measure satisfaction and quality, interviews, cross-institutional comparison, self evaluation and a literature review. Content analysis of the open responses followed. Essentially the programme was found to be very valuable, despite the high intensity and low spread. It needed to have greater spread, lower intensity and be linked to the Probation Policy to be taken more seriously. It was concluded that the policy needed to be reviewed. Recommendations were made to senior officers, one being that Induction become a process over a year. (153 words)
\end{abstract}

Keywords: Induction; inductees; presenters; evaluation; action research

\section{Introductory Background}

Induction falls under the umbrella of staff development (SD) which Blackwell and Blackmore (2003) feel "has no settled meaning, but is mostly effective if it engages with its sponsoring institution's key concerns." (Blackwell \& Blackmore. 2003:1) The institution under study has three forms of Induction for academics: Institutional Induction, Departmental induction and the Teaching and Learning Centre (TLC) Induction. The TLC Induction programme (IP) was initiated in 2007 at this university with the funding of South African Norway Tertiary Education Development (SANTED). It is a cyclic programme which runs in January and in June / July each year. When introduced, the programme was objectives-driven, which correlates with the Blackwell and Blackmore definition. The purpose of Induction as stated in the Induction Policy is "to make new employees feel at home in their new positions and working environment as quickly as possible so as to allow them to contribute effectively as soon as possible." ( Induction Policy, n.d.:1) It is designed to assist new staff members to familiarise themselves with the institutional history, expectations, processes and procedures; to refresh their knowledge of teaching and learning paradigms; to introduce them to the institutional approach to Community Engagement and Research (two other important pillars other than teaching and learning); to introduce them to the different support services; to provide opportunities for bonding and bridging with colleagues and important role players and to facilitate their adjustment to the university community as smoothly as possible ( Induction Policy objectives:1). The focus in this paper will be on the TLC IP as experienced by newly appointed staff members, called 'inductees' from now onwards. The use of the word 'teachers' in literature is please to be understood as being synonymous with 'lecturers' and their professional role.

On accepting the coordination of the TLC IP in October 2009, the coordinator found that the level of acceptance to the invitation to attend was under $50 \%$. After reading through the previous six reports on Induction and reflecting on the feedback given in evaluations, it became clear that attendance, at that stage, was the biggest challenge needing to be addressed and, secondly, the perception of Induction being a 'once-off' or 'train-and-release' programme. The inductees who attended the programme found it very useful, so from their perspective, it was successful because a range of useful tools and services had been introduced to them. From the organisational perspective though, the opportunity for new staff members to familiarise themselves with institutional objectives as described above was not being maximised if only 40 $50 \%$ of new staff accepted the invitation to attend Induction. 


\section{Literature Review}

Literature reveals that Induction can be viewed from an operational perspective in terms of drivers, the nature of the programme, the material covered, the programme's duration and in terms of agency. White, Bloomfield and le Cornu (201: 181) suggest that three key educational drivers are 'productivity, participation and quality'. They add that partnerships, standards-based preparation and professional learning across diverse contexts are beneficial to those preparing for a teaching profession. They further report that the Australian Government is 'targeting critical points in teacher 'life cycles' to attract, prepare, place, develop and retain quality teachers' ( White et al 2010:182). The importance of retaining quality teachers is also addressed by Edward $(2003,226)$ who stresses the importance of transition mechanisms in obtaining the commitment which ensures persistence'. Nixon and Ranson (1997) describe moral purposefulness and how an occupational group derive their professional identity from their listening and learning capacities and their abilities to move forward with the communities they serve. Ming-Chen (2003) concurs with this by explaining how identities are formed in the context of professional institutions and this centralises how embedded they are in the social space provided by such institutions. The researcher contends that joining a new institution should be viewed as a 'critical point' because the IP tries to prepare, develop and retain the new staff by making the transition as seamless as possible.

When considering the nature of the programme, it can take the form of workshops, formal programmes with high intensity and low spread or vice versa, or it can be informal in nature. Edward (2003) describes a resource-intensive programme with concentrated staff involvement and dedicated venues with minimal interruption as pre-requisites for their novel approach to induction of school leavers into university (possibly new staff members into positions at tertiary institutions too?) as including:

- the "use of experts and multiple sources which encourages evaluating information in relation to its source;

- discipline-related speakers to engender occupational commitment, subject relevance and note-taking skills;

- using multiple communication media and information sources to familiarize participants with systems and resources and develop generic skills;

- interrogative facilitator intervention which encourages effective study strategies, peer cooperation and institutional commitment;

- a 'treasure hunt' which ensures familiarization with the premises and key locations within the university.

Some researchers move away from the train-and-release approach to Induction towards an emphasis on the learning process per se where interventions of round-table discussions or off campus speakers and focus group discussions as development activities are found to be more beneficial. Lave and Wenger see this situated learning occurring where people are mutually engaged in learning from each other in a common activity. From this perspective, learning is a social act, coming from interaction with others and participation in life (Smith, 2003). In such development activities, the learning is more informal and social and participants seek and use feedback (Blackmore et al, 2006: 377); (Knight \& Trowler, 2000). These approaches to learning acquisition are fundamentally driven by the concept of selfregulated learning as opposed to learning enforcement which relies on designated facilitators. It becomes clear that the learning process occurs, particularly in communities of practice, during debate, dialogue, networking, guidance, support, critical reflection and mentoring which Lave \& Wenger classify as legitimate peripheral participation and situated learning' (Lave and Wenger, 1991:29). Tennant (1997:77) is of the view that knowledge needs to be contextualised and learning situated in a community of practice.

The material to be covered in staff development is largely policy-related and context- specific. Bitzer \& Kapp (1998), Le Grange (2004), Fraser \& Walberg (2005) and Brew \& Boud (1995) are of the view that staff development encompasses far more than improvement of skills. It entails familiarising individuals with institutional interests, processes and procedures, horizontal and vertical structures and programme offerings. Being exposed to these facets could lead toward mutual growth. Crossley (2006) Patulny \& Svendson, (2007) and Field (2003) suggest that the above mentioned line of thinking aligns well with Social Capital Theory. Under that umbrella, Induction programmes could be viewed as determinants because they impact on social interaction horizontally and vertically. This brings to attention the negotiated dialogic space between Deans, Directors, Managers, Heads of departments, existing lecturers and the newly appointed staff members; how they meet in that space, the types of academic pressure they feel. The organisational culture also seems to be ever-changing as staff members come and go. Field proposes that "human interaction and human relationships endure and enable people to build communities, commit themselves to one another" and share with one another (Field, 2003: 1-2). Together 'these capabilities yield results of greater value than would have been possible without human interaction' (Crossley, 2006: 286) (Patulny et al, 2007) Lin, 2001). Investment in social capital therefore 
has merit.

Granted, new staff members are inducted into a specific academic community and the complexity of how it functions. They also submit to rules, processes and realities of such a community as a pre-condition to finding their academic voice within such a community. Staniforth and Harland (2006:194) suggest that Heads of Departments (HODs) see their role as "implementing systems" where as inductees need to know how they fit into the institution, how they can become productive and become stayers (similar to Edward's commitment to perseverance). Trowler and Knight's sentiments (1999) and those of Kelley (2004) are echoed who contend that induction programmes may decrease teacher attrition rates and contribute to perseverance and effective teaching. Parsloe (1999) suggests that coaching as a developmental process has adaptation to role and environment as one of its targets and the expectation that work perspectives will be gained during this time. Stinchcombe (2001:21-41) puts forward conditions of abstraction, namely, that (a programme) must be "cognitively adequate" and suited to its purpose; be cognitively economical so that nothing unnecessary is included and the "scope of the formalisation must be applicable to most of the situation".

If a programme is relevant, the next factor to consider is agency. Van Keulen (2009) in reviewing Ann Stes's doctoral dissertation suggests that we can expect large effects in programmes that are specifically needs-based. Guskey (2002) suggests that there is an expectation that knowledge and skills will be expanded, whilst at the same time lecturers being given workable ideas for classroom management. He adds that the James-Lange Theory has merit in that he has also found that teachers' attitudes and beliefs generally change only after they have seen positive changes in student learning. At that crucial stage, continued follow-up and "support coupled with pressure is essential" (Guskey 2002:388). Bensimon, Ward \& Sanders (2000) suggest that a pivotal figure in departmental induction is the Head of Department who operates from a position of power in terms of workload distribution, but can also play a huge role in social adjustment of inductees by providing resource support, mentoring and evaluation. Knapczyk, Hew, Frey and Wall-Marencil (2005) also recommend mentoring. Whitaker $(2000 \mathrm{~b})$ reiterates this together with the need for emotional support, materials and policy documentation and the fact that inductees value being observed in a contact session. Furthermore, Whitaker indicates that frequent checking-in is valuable (Whitaker 2000c). Gersten, Keating, Yovanoff and Harniss (2001) emphasise the importance of learning about teaching. Billingsley, Carlson and Klein (2004) suggest that informal support is more valued than formal support. Staniforth and Harland (2006) add that there is very little real understanding of the potential of induction and that this is particularly evident in the lack of personal action by inductees. The inductees do not see the personal responsibility that is implied nor the opportunity to network and develop social relationships horizontally and vertically.

Various researchers have put forward thoughts on the duration of Induction programmes. Bay and Parker-Katz's view (2009) is that inductees require a minimum of a year's support and that policy should contain the full continuum of support required. Ingersoll and Strong (2011) add that programmes of longer duration and greater depth of support appear to be better. They also suggest that context and setting are contributory factors. Glazerman, Isenberg, Dolfin, Bleeker, Johnson, Grider, and Jacobus (2010) suggest that benefits are only evident after two years of support. These differences in the spread and density of Induction programmes can be due to many contextual and institutional factors which can be addressed in another paper.

\section{Theoretical Framework}

Since inception of the IP, coordinators have had a problem with the response rate to invitations to attend. Although Human Resources Department state in new employees' letters of appointment that the IP is compulsory to attend, many new staff members fail to respond to the invitation. Secondly, the programme has become fuller and fuller, with heavy concentration and low spread. This is a concern because inductees can become overloaded and lose interest and enthusiasm. The considerations therefore are whether the programme should continue as it is or whether it should be developed further perhaps as a process over a year, with submission of a portfolio of evidence which could be linked to a probationary year with policy implications. Given this, the aim is to conduct action research to address these issues so that the IP can be improved and developed. The research question, for the reasons mentioned above, is two pronged: should one continue with Induction and secondly, what should the nature of the programme be. Phrased differently, how can the coordinator influence and improve the Induction programme to increase uptake in a meaningful way? The coordinator is concerned firstly because policy is not being respected and/or policed and secondly, non-participants are missing the opportunity to adjust quickly to their new roles through guidance, interaction / networking and discovery.

There are a number of adult development and professional development theories such as the Age and Stage Theory, the Cognitive Development Theory, the Functional Theory or Guskey's Professional Development and Teacher Change Theory, but for the purposes of this paper, the last mentioned theory will be used as a framework. In 'Model of 
Teacher Change', Guskey (2002:383) holds that teachers want to experiment with new ideas and strategies in the comfort of their classrooms so that they can see the evidence of improved student learning before they will consider changing their beliefs and attitudes. Such improvements could result from use of different teaching strategies or introduction of new material or teaching aids or even from a change in procedure or classroom format. When an instructional approach is implemented successfully and seen to work, that experience changes the person's attitudes and beliefs. At Induction, one and a half days are devoted to student support services and teacher development support. Teaching paradigms are discussed together with teaching strategies so that inductees can reflect on them critically and make informed changes. 'This model of change is predicated on the idea that change is primarily an experientially based learning process for teachers' (Guskey 2002:384). If the teacher experiences difficulty in improving the learning outcomes of educationally disadvantaged students, then the teacher is likely to believe that those students are not capable of achieving academic excellence. As soon as another approach is used and results improve, the teacher is encouraged and in time, the beliefs of the teacher will change too. This theorist, therefore, contends that adult/professional development initiatives will bear fruits in time and that the time and space needs to be created for this development to occur. Guskey identifies various implications, namely, that change is a gradual and difficult process, that teachers require regular feedback on student learning progress and that continued follow-up, support and pressure need to be provided (Guskey 2002: 386-388).

Human beings and the world are interacting at many levels and we are continually gaining knowledge and discovering new things. There is always more to learn and know because learning is a lifelong process. Hopefully this action research will yield some solutions for the coordinator. The inductees, in turn, will be set on their road to discovery via the TLC IP, amongst other staff development efforts orchestrated by HR and the Research Centre.

\section{Methodology}

Research can be conducted in various ways. Action research aims to solve issues faced by practitioners so as to improve their understanding of the problems and to improve their action within practice, thereby developing it. It can be implemented in a collaborative context with data-driven collaborative analysis to develop understanding of underlying causes. The figure below illustrates the Induction cyclic process graphically:

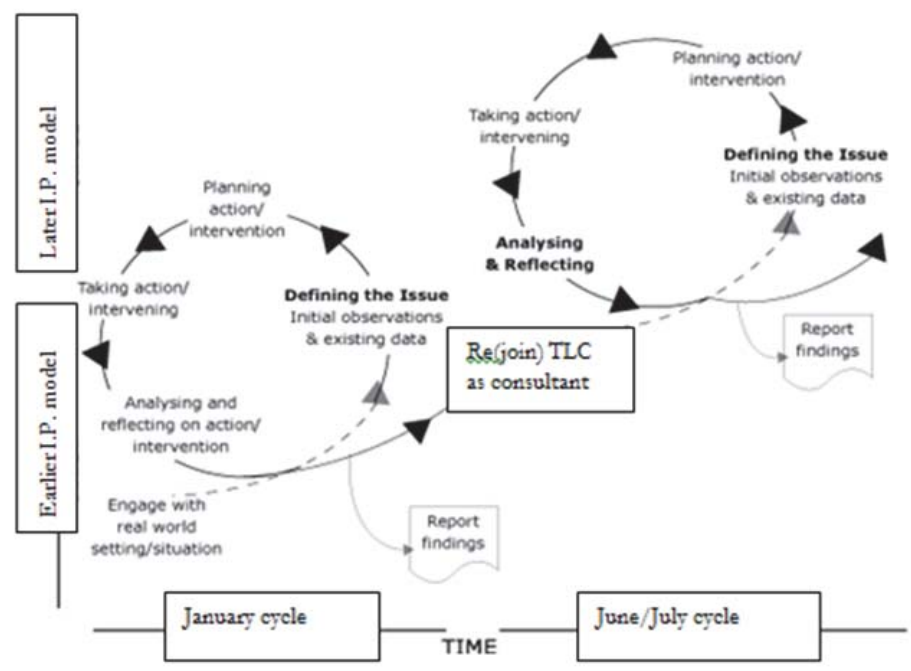

Figure 1: Research-in-action on Cyclic Induction Programme (Adaptation of Muir (2007)-Source: http://emedia.rmit.edu.au/edjournal/Action+research+in+the+scholarship)

As the figure shows, the inquiry process commences when problems are identified. Possible solutions or interventions are put forward which are then implemented and then evaluated. One then reflects on those findings to identify the second set of issues to be addressed in the next cycle and so the process continues as one develops and refines a 
programme in action.

Because evaluation forms an integral part of the action research undertaken for this study, it is important to include a definition of evaluation. The Joint Committee on Standards for Educational Evaluation defines it as "the process of determining the worth or merit of an activity, program, person or product." (In Certificate in the Facilitation of Learning Course Reader and Worksheets 2009:90). The purposes of evaluation at this institution are covered broadly by three things: for professional growth and development, for quality assurance reasons and for meeting national policy requirements. These policy requirements arise out of legislation from the Education Act. These requirements come to educators through the Higher Education Quality Assurance Committee (HEQC), the SAQA Act and through the Higher Education Amendment Bill. Each institution has its own institutional policies which staff members have to read in conjunction with the above national ones. Amongst these are the Assessment and Moderation of Student Learning, Admissions and the Induction Policies.

This institution's Induction Programme (IP), is relatively well established, so evaluation focus is not on implementation, but on the development of the programme in order to determine relevance. The evaluation plan has to fit the needs of the programme so that was the reason for the development of an impact survey. It was deemed necessary because impact is not something one can easily quantify. Many of the questions required qualitative or ranked responses.

Feedback received from participants is highly valued. It enables continual renewal and adjustment of approach, foci, material and presentation style from cycle to cycle. Evaluation, no matter how thorough, is a waste of time if the results do not inform change. If needs are being well met and the programme is still relevant, changes are not made. However, if weaknesses are highlighted and solutions put forward which are realistic and favourable, then executive management team (EMT) permission is sought to implement these changes. Because the IP is cyclic, action research is the avenue to follow.

Krockover, Adams, Eichinger, Nakhleh and Shephardson (2001) suggest that action research-like methodology offers a tool for transformation and improvement of learning; it allows systematic analysis of the impact of innovations and it also allows adaptation to the needs of the institution. This is important when one considers that each institution has unique needs. On assuming the role of coordinator, the author took the secondary data and carried out documentation analysis of programmes offered, evaluation responses captured and reports submitted from 2007 until Oct.2009. The tabulation under findings will display the most pertinent aspects revealed. It was decided that an action research approach would best benefit the participants in the programme so use was made of the approach /methods recommended in Hendry (no date) which will hopefully present enough data for meaningful analysis and triangulation:

First person action - requires that the I P Coordinator use an inquiring approach to involvement with the Induction Programme, to reflect on and question each issue before implementing solutions. The coordinator needs to be open to different viewpoints and sensitive to new thinking as she seeks to find her purpose in what is happening in the IP and what part she is playing in the creation and sustenance of how the programme operates, how and why inductees participate and interact at all levels and why they do not. She thus completed the self evaluation questions recommended in Reason's article.

Second person practice - a two-pronged approach was used here to heighten objectivity. Firstly, issues of mutual concern were discussed with a peer who has shadowed the coordinator before (she was interviewed and the dialogue recorded and captured). Secondly, a purposive sampling was carried out by distributing a purposefully compiled questionnaire to two cycles of inductees, the January and July 2012 groups. The line of enquiry centred on whether the IP should continue or not, its nature, strengths and weaknesses and ways of improving it. Participants were also asked about their view of linking the IP to a probationary year. The data from the open-ended questions evoked qualitative and quantitative responses. The respondents would be representative of the different departments and faculties in which they work and they would vary in seniority and rank. The request to participate needed to be framed as a mutual process of inquiry. In the questions posed to inductees, the coordinator needed to establish if there was resistance to attending the IP and if there was, why. These findings and recommendations could then be included in the August report 2012 to the EMT for their consideration.

Third person research - an impersonal quality could be gained by creating a wider community of inquiry. An incoming cohort, unknown to each other, was thus surveyed to gain a perspective of their previous experiences and their expectations when joining our institution. They could proffer viewpoints on which slots draw the most interest, based on the institutions they have previously served. Secondly, by sharing the questionnaire with regular presenters also, the coordinator could get their perspectives of the programme. The coordinator then included a third party by contacting another institutions' staff development practitioner and asked her to input their institution's policy, practice, process and response rate.

Each participant was assured of confidentiality and anonymity in writing. Consenting participants submitted their 
responses via email or through a collection box positioned in a strategic place. Those who were reluctant to participate, did not respond. Completion of the questionnaire was thus equated with written consent. The purpose of having one administrator and capturer was to keep the method consistent. This strategy also heightened the reliability factor in terms of interpretation.

By adding a literature review to these three lenses, together the four perspectives would present the 'big picture' and objectivity would be heightened. After critical reflection on all the feedback received, usefulness would be established.

The data collected was captured and themes were generated inductively by reading and rereading the responses. The identified themes were then coded and categorized. This categorization was followed by analysis and interpretation of participants' perceptions. The aim was to gain an understanding of the participants' perceptions of the IP and its worth because the social well-being of inductees is important. The four lenses allowed for triangulation of the data. If recommendations were accepted by EMT, they could be implemented in the next cycle. In that way they would build on previous actions from cycle 1 to cycle 2 to cycle 3 etcetera in an on-going action research manner. Such improvements implemented would strengthen the programme. In this way the coordinator would not necessarily solve all the challenges faced, [such as the possible reasons for behaviour (some accepting the invitations, others not; some completing the Impact assessment, others not) before seeking to change the programme again, but she would be creating a space for continuing dialogue.

\section{Findings}

To make the cyclic findings around issues and solutions since inception of the IP succinct, they will be tabulated and then discussed, focussing mainly on the data from the 2012 cycle of action research implemented:

\begin{tabular}{|c|c|c|c|}
\hline TIME & ATTENDANCE RATE & MAIN ISSUE/S & SOLUTION IMPLEMENTED \\
\hline 2007 Jan. cycle & $\begin{array}{c}6 \text { of } 12(50 \%) \text { with only } 4 \\
\text { attending all } 4 \text { days }\end{array}$ & $\begin{array}{l}\text { Communication with new staff. } \\
\text { Lists of new staff made available too late for } \\
\text { contact to be made and attendance assured. }\end{array}$ & $\begin{array}{l}\text { Stipulate mandatory attendance of induction in appointment } \\
\text { letter sent by HRD. Include contact details of HR staff and TLC }\end{array}$ \\
\hline 2007 June/July & \multicolumn{3}{|c|}{ CANCELLED BY HR DEPARTMENT } \\
\hline 2008 Jan. cycle & $\begin{array}{c}16 \text { (no record of potential } \\
\text { numbers) }\end{array}$ & $\begin{array}{l}\text { Some inductees are really new, others have been } \\
\text { in system for } 4-5 \text { months which creates } \\
\text { challenges for them if HR and Finance processes } \\
\text { and procedures are not dealt with earlier than } \\
\text { Induction } 6 \text { monthly }\end{array}$ & $\begin{array}{l}\text { Either a manual or electronic instructions plus samples and } \\
\text { templates will be circulated by the relevant parties }\end{array}$ \\
\hline 2008 June/ July & \multicolumn{3}{|c|}{ No records bar the programme and author's own attendance as an inductee } \\
\hline \begin{tabular}{|c|}
2009 Jan. \& \\
June
\end{tabular} & \multicolumn{3}{|c|}{$\begin{array}{l}\text { July Induction cycle cancelled due to financial situation at the institution. No data found on January bar the close out report for SANTED } \\
\text { indicating positive attitude towards continuance, with suggestions about programme length and topics to be handled. }\end{array}$} \\
\hline$\frac{\frac{\text { On assumption }}{\text { of role, October }}}{2 \text { 2009: }}$ & & & IP to continue \\
\hline $\begin{array}{l}\text { End of January. } \\
\text { 2010: }\end{array}$ & 13 of $27(48,15 \%)$ & \begin{tabular}{|l} 
Presentations too long and discussion time too \\
short. \\
Accommodation in Fort Beaufort not acceptable to \\
all inductees because of poor security ( no burglar \\
bars on windows) \\
Compulsory attendance not enforced by HRD nor \\
Deans through HODs \\
\end{tabular} & $\begin{array}{l}\text { Shorten presentations and increase discussion time. Upload } \\
\text { resources on Blackboard. } \\
\text { Introduce a Follow-Up day } 6 \text { months after induction to provide } \\
\text { second platform } \\
\text { Try to use Hogsback venues in future. } \\
\text { Approach Deans directly and ask for their support }\end{array}$ \\
\hline \multirow[t]{2}{*}{$\begin{array}{l}\text { End of July } \\
\text { 2010: }\end{array}$} & $\begin{array}{l}\text { Induction cancelled by } \\
\text { HR Dept. } \\
\text { 61,5\% attendance of } \\
\text { Follow-Up Day } \\
\text { introduced for January } \\
\text { inductees. }\end{array}$ & $\begin{array}{l}\text { 'Train -and -release' approach is not meeting all } \\
\text { inductees' needs. } \\
\text { For academics, add slot on Community } \\
\text { Engagement, Foundation Provisioning, on-line } \\
\text { course management. } \\
\text { Create a separate programme for support staff } \\
\text { after topics that are common to both groups have } \\
\text { been handled. }\end{array}$ & $\begin{array}{l}\text { Provide Induction with a greater spread including } \\
\text { developmental activities at regular intervals, including } \\
\text { consultation sessions, observation of teaching / contact } \\
\text { session and offer another platform in the form of an inductee } \\
\text { newsletter.. } \\
\text { Introduce a break away for support staff after day } 1 \text { into } \\
\text { different venues with different topics for presentation, asking } \\
\text { HR to suggest topics relevant to administrative and } \\
\text { maintenance personnel. }\end{array}$ \\
\hline & $\begin{array}{l}\text { DVC requested that TLC } \\
\text { take over Induction } \\
\text { programme from HR } \\
\text { Dept }\end{array}$ & & $\begin{array}{l}\text { Train up } 2 \text { OD officers from HR so that they can take back the } \\
\text { programme after 1- } 2 \text { years }\end{array}$ \\
\hline
\end{tabular}




\begin{tabular}{|c|c|c|c|}
\hline $\begin{array}{l}\text { End of January } \\
\text { 2011: }\end{array}$ & 14 of $37(37.84 \%)$ & $\begin{array}{l}\text { Huge amount of information to absorb over short } \\
\text { time. } \\
\text { Include more out of class activities please. } \\
\text { Low acceptance rate to invitation to attend } \\
\text { Induction }\end{array}$ & $\begin{array}{l}\text { Upload info on Blackboard for access at any time. } \\
\text { Include visit to Archives after Library. } \\
\text { Ask HRD and Deans to encourage attendance }\end{array}$ \\
\hline $\begin{array}{l}\text { End of July } \\
\text { 2011: }\end{array}$ & 14 of $33(42,42 \%)$ & $\begin{array}{l}\text { Files of information unwieldy. } \\
\text { Expand on support service programme } \\
\text { Programme too intense. } \\
\text { Spread it out. }\end{array}$ & $\begin{array}{l}\text { Introduce CDs that are compact and portable. } \\
\text { Create slots for half of Day } 2 \text { for Support staff. } \\
\text { Introduce monthly seminars in } 2012 \text {. }\end{array}$ \\
\hline $\begin{array}{l}\text { End of January } \\
\text { 2012: }\end{array}$ & 20 of $31(64.52 \%)$ & $\begin{array}{l}\text { Still want more discussion time. } \\
\text { Finance presentation has bureaucratic tone and } \\
\text { inductees feel discouraged to participate in } \\
\text { projects after hearing financial implications. } \\
\text { void running programme during staff vacation - } \\
\text { they need their rest. }\end{array}$ & $\begin{array}{l}\text { Circulate presentations } 2 \text { weeks before Induction so that pre- } \\
\text { reading is done and inductees come prepared with questions } \\
\text { for discussion time. Introduce world café discussion groups. } \\
\text { Ask presenters to focus on salient features and allow longer } \\
\text { interaction and discussion time. } \\
\text { Try using } 1^{\text {st }} \text { week of term } 3 \text { for next cycle (against own better } \\
\text { judgement and experience) }\end{array}$ \\
\hline $\begin{array}{l}\text { End of July } \\
\text { 2012: }\end{array}$ & 45 of $54(83.3 \%)$ & $\begin{array}{l}\text { Programme must run when student are on } \\
\text { vacation or in recess. } \\
\text { Expand Support Staff Programme further. }\end{array}$ & $\begin{array}{l}\text { Revert to using first or last few days of vacation time so that } \\
\text { tudents are not affected when staff inductees attend } \\
\text { Induction. } \\
\text { Additional presenters approached and programme lengthened } \\
\text { for } 2013 \text { to two full days for Support Staff }\end{array}$ \\
\hline $\begin{array}{l}\text { End of Jan. } \\
\text { 2013: }\end{array}$ & 23 of $33(69.7 \%)$ & $\begin{array}{l}\text { Acceptance rate of invitation is still not ideal } \\
\text { Request campus tour and longer interaction. }\end{array}$ & $\begin{array}{l}\text { DVC, Deans and HODs to encourage uptake } \\
\text { Hold this decision until reiterated so it can become part of } \\
\text { following year's solutions to implement }\end{array}$ \\
\hline $\begin{array}{l}\text { End of July } \\
\text { 2013: }\end{array}$ & 56 of $70(80 \%)$ & $\begin{array}{l}\text { Request campus tour } \\
\text { nvite Labour Union representative to address } \\
\text { inductees } \\
\text { HRD OD officers should become more involved }\end{array}$ & $\begin{array}{l}\text { Include campus tour before VC's Welcome ceremony and } \\
\text { extend to } 4 \text { day programme again so as to include Union rep } \\
\text { and } 1 \text { or } 2 \text { other relevant slots. } \\
\text { HRD OD officers take back full responsibility of administrative } \\
\text { and organisational side of Induction plus Support Staff } \\
\text { programme if January } 2014 \text { cycle runs well, leaving only the } \\
\text { Academic Programme to the TLC, so that TLC staff can get on } \\
\text { with their core business.. }\end{array}$ \\
\hline
\end{tabular}

For purposes of this paper, only the 2012 cycle's action research feedback from the survey will be discussed fully. There was a $36.7 \%$ average response rate from presenters, inductees and future inductees. All respondents unanimously acknowledged the need for an Induction programme and they supported the attendance of Induction for various reasons, including the following:

- "It is an introduction to the operations and procedures followed at this institution, policies, rules and regulations which differ greatly from institution to institution"

- "Different contextual elements and own culture".

- "It is an opportunity for networking with different departments."

- "The activity portrays a warm, caring and welcoming environment. Adjustment is made easier. We work in a very complicated world; everyone is very busy in his or her own corner. After the induction, networking develops into collaborative and meaningful engagements for the best of the institution/clientele."

- One incoming staff member from another institution said, "A good induction programme serves to build in the new employee such attributes as confidence, loyalty, and productivity. It would equally reinforce in the incoming staff with the ability to perform his/her duties without minimal likelihood of workplace rule violation. In fact induction is a very important first step that ensures that the new or incoming staff member is fully admitted into the new work environment."

The main reasons given for its under-utilisation were:

- "The value is not appreciated before the fact, so it becomes easy to prioritise other matters over induction".

- "It is not mandatory".

- "Faculties and HOD's need to know about this and support it. They do not."

- "If HR can collaborate with TLC, the programme can be adequately utilised."

- "As an incoming staff member, I am not yet familiar with TLC induction at this institution. However, as a matter of fact, this action research approach used by the TLC is a pointer to the fact that TLC at this varsity is up and running."

To the question as to how the acceptance rate to the invitation could be improved, the following responses were given: 
- " "The induction should be made compulsory and dates for attendance should be on the employment letter."

- "Follow up communication on the importance of the induction programme telephonically with new staff."

- "Deans and HODs should be accountable for staff not attending."

- "Make it part of the employment contract or a condition for final appointment; a probationary requirement."

- "By extending more invitations to non-academics instead of focussing on academics when the advert goes out."

- "Invitations should be sent by the Vice Chancellor or DVC. Lower level officials have no clout hence are not taken seriously by academics."

- "Perhaps more marketing and giving away of incentives over Induction, like varsity mugs, would encourage attendance."

Regarding how the Induction Programme could be improved, the following responses reflected most of the suggestions received:

- "Being spread over a whole semester or year in smaller doses would have greater impact.".

- "Making sure that the inductees understand the aims/objectives of the induction."

- "Make it compulsory and give incentives away, like a mug."

- "Finding a quality off campus venue and enforce attendance."

- " "Send presentations to inductees and supply information or diagrams of processes or procedures."

- "Investigate possible activities relevant to administrative staff and provide them

- " "The part for the admin. staff was very short so please extend it."

- "There were departments like quality assurance and finance that did not complete their presentations and/or question and answer sessions were limited. Allow more time for this."

- " "Provide the induction pack in advance."

- "Cut out unnecessary activities."

- One incoming staff member not yet here said: "It may be helpful to make induction a periodic event instead of a one-off. The tendency (experience has shown) is for induction programme to be intensive and for a short period with the impression that all is now well with the new staff. However, a periodic refreshing induction could complement what has already begun during the first induction programme. This could serve as a genuine opportunity for a staff member to renew his/her commitment to the organisation."

To the question of how the time could best be utilised without compromising the quality of presentations, such suggestions were given:

- "Get inductees to access online discussion space, through Blackboard or the Intranet where inductees can go to get more information about institutional operations and the TLC."

- "If the programme is spread over a longer time, but in smaller doses, you could have an initial session at the usual times for the new people, but stick to the 'getting started' stuff. Then follow up with a more extended programme that addresses deeper issues of T \& L."

- "More time is needed so that the participants can have enough time to process information properly, too little time allocated defeats the purpose of induction."

- "Circulate presentations beforehand to all. Let them come prepared."

- " "Further questions should be left to supervisors and HRD team leaders."

- "Presentations or the materials to be covered can be e-mailed prior the induction so that most of the time can be spent on questions and answers."

- "The material needs to be added to the documents we receive when we assume duties so that less time can be spent during the induction."

- " "Compile written presentations and circulate them in time."

- An incoming staff member not yet here said:

"Emailing presentations and documents before Induction would go a long way. Secondly, since time is always very unfriendly during induction, it may appear helpful to prepare well detailed and informative handbooks and handouts for inductees to take home."

\section{Discussion}

Responses seem to fall into three themes, namely, the importance of Induction, communication and policy. The reasons 
given above for why Induction is so important are aligned with the aims and objectives as outlined in the Induction Policy and by the coordinator. They also support Ingersoll \& Strong (2011); White, Bloomfield and le Cornu (2010); Edward (2003); Nixon \& Rawson (1997); Ming-Chen (2003); Bitzer \& Kapp (1998), Le Grange (2004), Fraser et al (2005), Brew (1995); Crossley (2006); Trowler \& Knight (1999); Kelley (2004) and Lin (2001) findings regarding the vital role of staff development programmes for inductees' transition into their new roles and its value as a tool for decreasing attrition rates.

The reasons given for under-utilisation or non-attendance of the programme were grouped around other priorities, misinformation and wrong perceptions. Other priorities included workload and familial obligations. Most misinformation and wrong perceptions arose around Induction being optional versus mandatory and around the drivers of Induction and the type of programme being offered. These groupings illustrate Staniforth and Harland's (2006) view that inductees need to know how and where they fit into the institution (2) before they will assess the possible benefit of attendance and commit to staff development activities. It also reiterates what Guskey (2002) suggested about teacher motivation and willingness to engage in professional development only after they have gained evidence of improvement in student learning; it is the 'experience of successful implementation that changes teachers' attitudes and beliefs' (Guskey 2002:383). This talks to change being`an experientially-based learning process' (Guskey 2002:384).

In terms of communication, the source of the invitation to Induction might be taken more seriously if sent by the DVC. Following up on inductees who had not responded could be done telephonically and reinforced by HOD's and Deans after their support had been solicited. This supports Staniforth and Harland's view (2006) of senior staff implementing systems and also that of Bensimon, Ward \& Sanders (2000) who describe the power relations inherent in institutional hierarchies that can be used in a positive, developmental way. Compilation of the programme enjoyed a small amount of attention in that some felt that the non-academics should have a longer programme than one day as previously had. It was suggested that the HR officials become involved in this. There was strong support for the programme, presentations together with supporting files and CD's being sent to inductees and/or uploaded on Blackboard for viewing a week or two before Induction. This approach is in line with Bensimon et al's (2000) and Guskey's (2002) suggestions of providing resource support to inductees. This would allow inductees to read through everything before the formal 3-day programme and then more time could be set aside for discussion and question -and- answer time. Whitaker (2000b) also recommends this as a tool: materials and policy documentation act as markers, give direction and facilitate agency. The coordinator cautions, however, that this rests heavily on the assumption that inductees would read the material. Proceedings could be hampered heavily should this not happen. Then the peer review suggested that a world café scenario could be used for the discussion time - this had already been instituted so it served as affirmation of the strategy.

The personality of an individual plus his / her professional knowledge will need to be supplemented by a processoriented education involving critical reflection, such as staff development programmes. The 'learning' that takes place at the Induction Programme can best be described as interactive and situational: inductees of different ages join university staff with differing degrees of prior knowledge and different levels of experience and these are shared during the discussion slots between presentations and within group work set as part of various presentation slots. This complex aspect of diversity is recognised very well in the Age and Stage Theories described by Trotter (2006). This underlines Lave and Wenger's views on situated learning activities (1991), that of Tennant (1997) and those of Billingsley, Carlson and Klein (2004) on the value of informal support. It also supports Smith (2003) on the value of social learning, Blackmore et al (2006) and Knight \& Trowler (2000); who value the social interaction and use of feedback. Evaluation feedback has shown that by opening up a participatory space over the past three years, increased value has been attributed to the programme. This has ironically presented a new challenge: Inductees feel IP is too intense - they either need more time on the programme or the formal offering needs to be shorter and lead to a denser spread, allowing more time for sharing and discussion. The question then arises as to which slots need to be transferred to another platform, and on which grounds these choices would be made. This would either be at the discretion of the coordinator, based on experience built over the years, or through consultation with executive management. Daskalali (2012: 93) underpins the view held by the coordinator that:

'New employee induction is a process, during which situated discourses construct an environment that surfaces current organizational assumptions and invites new interpretations to emerge. This environment or space can become a reflexive, interventionist arena for jointly effecting proactive change initiatives and dialogical organizational development'.

The author agrees with Lynton (1995) who holds that professional competence requires a broadened understanding of expertise, a greater depth of knowledge and critical thinking ability. The opportunity for creativity exists 
because of variables such as prior knowledge; past and present experiences; the location of the IP; changes in coordinators of the programme; staff work load and available resources such as Blackboard. Unfortunately, the IP is also classified by some staff as 'soft knowledge' with low academic status (Corridor talk 2012) so it would require a change in mindset before the programme could demonstrate its full worth. However, evaluation responses indicate fairly strong support for a probationary year being built into policy, which might force inductees to take the matter more seriously. It was suggested that Induction become a probationary requirement. This is in line with Bay and Parker-Katz's view (2009) that inductees require a minimum of a year's support and that policy should contain the full continuum of support required. The coordinator contends that by submitting a portfolio that is criterion-referenced, new staff members would be aligning theory to practice and would also be more exposed to situational learning. Carter and Feiman-Nemser (2009) suggest that the way ' induction is defined shapes the nature and duration of support offered and the programmatic tools and resources provided'.

It would seem that resistance to attending the IP is based on conflicting interests or calls upon their time; personal reasons, e.g. not wanting to leave their families for two nights or insecurities about implications, e.g. possibly needing to change teaching style or emotions such as arrogance (e.g. "What can you teach me if I've been a lecturer for 30 years?"). The fact that attendance is mandatory is minimised because of inductees knowing that policy is not policed. The inductees' prejudices seem to rest heavily on misconceptions about the purpose and intended outcomes of the programme. Possibly if the programme had a lower density and greater spread by having a link to a probationary year for contract purposes, the suggested criterion-referenced portfolio documenting theory and practice of teaching and learning, plus evidence of assessments and evaluation would demonstrate greater value and result in increased uptake. Hopefully if the coordinator can provide a clear vision of how the change will affect the inductees, they might not resist as strongly. Coercive tactics should not be required because TLC operates on the principle of working with the willing! When viewed against the developmental approach TLC usually adopts, inductees will realise that the Induction coordinator will always have a safety net for them and that staff development practitioners also provide positive role models. Perhaps it would be good to provide specific details about possible changes and then invite discussion so that the reasons for resistance can surface and be heard. Muddy areas can then be clarified before the resistance is explored. It is hoped that inductees will be comfortable with the communication and consultation and that they will come to accept that the change the coordinator is trying to bring about is aimed at addressing their needs: there is a strong feeling that they can maximise their potential for expertise by being open to the changes being proposed. If the suggestion of a probationary year is accepted by the EMT, then that would also be in line with Bay and Parker-Katz's view (2009) and Ingersoll \& Strong's (2011) that a minimum of a year is recommended strongly for Induction.

\section{Conclusion}

By implementing, observing and reflecting on the Induction programme after each cycle, certain issues that needed to be addressed came to light. The programme is meeting inductees' needs and it needs to continue. However, the nature of the programme needs to change from being objectives-driven to participant-oriented through a process over time. The feedback received from the action research instituted will drive the changes for implementation during the 2014 cycles. The effect of these changes will be captured in the evaluation of each cycle. Having asked questions and having collected the data on which to reflect critically, a fresh understanding has been reached which should equip the 2014 coordinators to provide an Induction that will be well received, that works towards staff retention, an Induction programme that is worthy of a higher educational institution trying to build staff expertise. Notwithstanding the aforementioned, a space for continuing dialogue will have been created. It is accepted that universities face significant challenges in initiating and socialising new staff members into their environments. Individual differences in socio-political, cultural, educational and linguistic background and experience compel institutions to explore ways of making the adjustment in the new work place as smooth as possible. The transformation needs to come from within - development must occur hand in hand with teaching and learning. Departments within faculties must realise that their setting strongly influences staff development. Experienced and more senior members need to exert their influence wisely by being informed about the Induction programme on offer and by being committed to affording new staff members the opportunity to participate to the full in their new community of practice.

\section{Recommendations}

With the importance of Induction reaffirmed, focus should shift to seeking the 'buy-in' and cooperation of the DVC, Deans and HOD's to drive a 'pro-acceptance' of Induction invitations in 2014. This united front should address the acceptance of 
invitation issue. Thereafter, TLC Induction coordinator and HR OD officials need to put their heads together to create a more comprehensive non-academic programme to meet the administrative and maintenance staff members' needs. Presenters will need to be informed of the decisions made regarding early distribution of presentations and resource material so that they can meet the earlier deadlines. When inductees are notified of the readiness of material, they can then also be informed of the decision to have hosts /hostesses at certain tables with a world café approach around all topics. Pre-reading must be stressed so as to ensure meaningful discussion. In this way the shortage of time will be addressed. Lastly, the Executive Management Team can be approached with these results and asked to consider the suggestion of Induction being a process over a year and that a probationary year be built into policy for 2014/2015.

\section{References}

Bay, M.and Parker-Katz, M. (2009). Perspectives on Induction of beginning Special Educators: Research Summary, Key Program Features, and the State of State-Level Policies. Teacher Education and Special Education 32(1)17-32. Accessed on-line on 27 February 2014.04.06 on http://tes.sagepub.com/content/32/1/17

Bensimon, E., Ward, K. \& Sanders, K. (2000). The Department Chair's Role in Developing New Faculty into Teachers and Scholars. Bolton: Anker.

Billingsley,B., Carlson, E. and Klein, S. (2004). The Working Conditions and Induction Support of Early Career Special Educators. Exceptional Children. Council for Exceptional Children. 70(3)333-347.

Bitzer, E. and Kapp, C (1998) A manual for new academic staff developers in Further and Higher Education. Centre for Higher Education. Stellenbosch.

Blackmore, P. \& Blackwell , R. (2006). Strategic leadership in academic development, Studies in Higher Education, 31(3) 373-387,. Accessed on 24 February 2010 on http://www.tandfonline.com/loi/cshe20

Brew, A. \& Boud, D (1995) Teaching and Research: Establishing the vital link with learning. Higher Education . 29: 261-273.

Carver, C. and Feiman-Nemser, S. (2009). Using Policy to Improve Teacher Induction: critical elements and missing pieces. Educational Policy. 23(2)295-328. Accessed on 25 February 2010 on http://epx.sagepub.com hosted at http://online.sagepub.com

Crossley (2006) Rethinking context in Comparative Education. 22: 1173- 1187 International Handbook of Comparative Education. Springer International.

Daskalaki, M. (2012). Recontextualizing New Employee Induction: Organisational Entry as a Change Space. The Journal of Applied Behavioral Science 48(1) 93-114. Accessed on 24 February 2013 on http://jabs.sagepub.com

Edward, N. (2003). First impressions last: an innovative approach to induction. Active learning in Higher Education. The Institute for Higher Learning and Teaching in Higher Education and Sage Publications. Vol 4(3): 226-242

Felder, R.M. (2000). The Scholarship of Teaching. In Chem. Engr. Education, 34(2), 144

Feiman-Nemser, S., \& Schwille, S. (1999). A conceptual review of literature on new teacher induction. Washington, DC: National Partnership for Excellence and Accountability in Teaching.

Field, J. (2003). Social Capital. Second edition. London. Routledge.

Fraser, B.J. \& Walberg, H.J. (2005). Research on teacher-student relationships and learning environments: context, retrospect and prospect. International Journal of Educational Research.. 43(1)103-109

Freire, P. (1970). Pedagogy of the Oppressed. New York: Herder \& Herder.

Gersten, R., Keating, T., Yovanoff, P., \& Harniss, M. K. (2001). Working in special education: Factors That enhance special educators' intent to stay. Exceptional Children, 67, 549-567.

In Daskalaki (2012) Recontextualizing New Employee Induction: Organisational Entry as a Change Space. The Journal of Applied Behavioral Science 48(1) 93-114. Accessed on 24 February 20123 on http://jabs.sagepub.com

Glazerman, S., Isenberg, E., Dolfin, S., Bleeker, M., Johnson, A., Grider, M., \& Jacobus, M.

(2010). Impacts of comprehensive teacher induction: Final results from a randomized controlled study (NCEE 2010-4027). Washington, DC: U.S. Department of Education.

Guskey, T.R. (2002). Professional Development and Teacher Change, Teachers and Teaching: theory and practice. 8(3)381-391.

Hartland, T. \& Stanisforth, D. (2000) 'Action Research: An Acceptable Path to Professional Learning for University Teachers?', Educational Action Research 8(3):499-514.

Henry (undated) Creative Management. London. Sage Publishers.

Ingersoll, R. \& Strong, M. (2011). The Impact of Induction and Mentoring Programs for Beginning Teachers: a Critical Review of the Research. Review of Educational Research.

Accessed on 24 February 2013 onhttp:// rer.sagepub.com/content/81/2/201

Kelley, L.M. (2004). Why Induction matters. Journal of Teacher Education. Vol.55: 438.

Knapczyk, D. R., Hew, K. F., Frey, T. J., \& Wall-Marencil, W. (2005). Evaluation of online Mentoring of practicum for limited licensed teachers. Teacher Education and Special Education, 28(3/4), 207-220.

Knight, P. T. \& Trowler, P. R. (1999) 'It Takes a Village to Raise a Child:Mentoring and the Socialisation of New Entrants to the Academic Profession', Mentoring and Tutoring 7(1): 
23-34.

Knight, P. T. \& Trowler, P. R. (2000) 'Departmental-level Cultures and the Improvement of Teaching and Learning, Studies in Higher Education, 25(1) 69-83

Krockover, G., Adams, P., Eichinger, D., Nakhleh, M.and Shephardson, D. (2001). Action-based Research Teams: Collaborating To Improve Science Instruction. Injecting Energy into Science Education. Journal of College Science Teaching. 30(5)313.

Lave, J. and Wenger, E. (1991). Situated Learning: legitimate peripheral participation. Cambridge University Press.

Le Grange, L. (2004) E-Learning: some critical thoughts: perspectives on higher education. South African Journal of Higher Education. 18(1) 87-97. Sabinet

Lin, N. (2001). Social capital: A theory of social structure and action. Cambridge University Press.

Lynton, E. A. (1995). Making the Case for Professional Service. Forum on Faculty Roles and rewards.

Ming-Chen, M. L. (2003). Modernity and the Social Formation of Professions. Conference Paper. American Sociological Association. Annual Meeting. Atlanta, GA. Pp. 1-42. Abstract.

Muir (2007) Figure illustrating action research in the scholarship. Accessed on http://emedia.rmit.edu.au/edjournal/Action+ research+in+the+scholarship

Nixon, J. \& Ranson, S. (1997) Theorising 'agreement': the bases of a new professional ethic, discourse, Studies in the Cultural Politics of Education, 18(2)197-214.

Parsloe, E. (1999). The manager as coach and mentor. Institute of Personnel and Development. Patulny, R. and Svendsen, G.L. H. (2007) Exploring the social capital grid: bonding, bridging, qualitative, quantitative, International Journal of Sociology and Social Policy, 27( 1,2)32 - 51.

Ramsden, P. (1998). Learning to Lead in Higher Education. London: Routledge.

Reason, P. (undated). Learning and change through Action Research . To appear in Henry, J. (ed.) Creative Management. Sage: London.

Reason, P. \& Bradbury,H. (2001). The Handbook of Action Research. Editors. Concise paperback edition. Sage publishers.

Rosser, V. J. (2003) 'Preparing and Socializing New Faculty Members', Review of Higher Education 26(3): 387-95.

Rugarcia, A., Felder, R., Woods, D. and Stice, J. (2000). The future of Engineering Education1. A vision for a new century. Chemical Engineering Education. 34(1) 16-25.

Smith, M.K. (2003). Communities of practice. The encyclopedia of informal education. Accessed on 23 September 2010 on www.infed.org/biblio/communities of practice.html

Staniforth, D. \& Hartland, T. (2003) Reflection on Practice: Collaborative Action Research for New Academics, Educational Action Research 11(1): 79-91

Stinchcombe, A.L. (2001). When formality works, authority and abstraction in law and organisations. Chicago. University of Chicago Press.

Tennant,M. (1997). Psychology and Adult Learning. London. Routledge.

The World Bank. (2003). Independent Evaluation: Principles, Guidelines and Good Practice. The World Bank Development Grant Facility Technical Note. Accessed on 21 August 2012 on http://aea365.org/blog/dovp-week-don- glass-on-applying-universaldesign-for-learning- udl-to-evaluation/

Trotter, Y. (2006). Adult Learning Theories: Impacting Professional Development Programs. Accessed on 30 March 2014 on http://web.b.ebscohost.com/ehost/pdfviewer/p.

Trowler, P. \& Knight, P. T. (1999) 'Organizational Socialization and Induction in Universities: Reconceptualizing Theory and Practice', Higher Education 37(2):177-95.

Trowler, P. \& Knight, P. T. (2000) 'Coming to Know in Higher Education: Theorising Faculty Entry to New Work Contexts', Higher Education Research and Development 19(1): 27-42.

University of Fort Hare. (2007). Induction Policy. University of Fort Hare.

University of Fort Hare. (2009). Certificate in the Facilitation of Learning Course Reader and Worksheets. University of Fort Hare.

Van Keulen, H. (2009) The impact of instructional development in higher education: effects on teachers and students, International Journal for Academic Development,14(2)163-165. Accessed on 19 February 2014 on http://www.tandfonline.com/loi/rija20

Wang, J., Odell, S., \& Clift, R. (Eds.). (2010). Past, present, and future research on teacher induction: An anthology for researchers, policy makers, and practitioners. Lanham, MD: Rowman \& Littlefield and Association of Teacher Educators.

Wang, J., Odell, S. J., \& Schwille, S. A. (2008). Effects of teacher induction on beginning teachers' teaching: A critical review of the literature. Journal of Teacher Education, 59, 132-152

White, S., Bloomfield, D. \& Le Cornu, R. (2010). Professional experience in new times: issues and responses to a changing education landscape. Asia-pacific Journal of Teacher Education. 38(3)181-193.

Whitaker, S. D. (2000b). Mentoring beginning special education teachers and the relationship to attrition. Exceptional Children, 66(4), 546-566.

Whitaker, S. D. (2000c). What do first-year special education teachers need? Implications for induction programs. Teaching Exceptional Children, 33(1), 28-36.

Yielder, J. (2004) An integrated model of professional expertise and its implications for higher education, International Journal of Lifelong Education, 23:1, 60-80, Access on 23 September 2010 on http://www.tandfonline.com/loi/tled20 